\title{
HISTORICAL BIOGEOGRAPHY OF NEOTROPICAL \\ FRESHWATER FISHES
}


The publisher gratefully acknowledges the generous contribution to this book provided by the University of Louisiana. 


\title{
Historical Biogeography of Neotropical Freshwater Fishes
}

\author{
Edited by \\ JAMES S. ALBERT \\ ROBERTO E. REIS
}

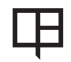


University of California Press, one of the most distinguished university presses in the United States, enriches lives around the world by advancing scholarship in the humanities, social sciences, and natural sciences. Its activities are supported by the UC Press Foundation and by philanthropic contributions from individuals and institutions. For more information, visit www.ucpress.edu.

University of California Press

Berkeley and Los Angeles, California

University of California Press, Ltd.

London, England

(C) 2011 by the Regents of the University of California
Library of Congress Cataloging-in-Publication Data

Albert, James S.

Historical biogeography of neotropical freshwater fishes / edited by James S. Albert and Roberto E. Reis.

p. $\mathrm{cm}$.

Includes bibliographical references and index.

ISBN 0-520-26868-5 (cloth : alk. paper)

1. Freshwater fishes - Latin America-Geographical

distribution. 2. Fishes-Tropics-Geographical distribution.

3. Historical geology_Latin America. I. Reis, Roberto E. II. Title. QL628.5.A43 2011

$597.176098-\mathrm{dc} 22$

2010024461

Manufactured in The United States of America

$\begin{array}{lllllllll}19 & 18 & 17 & 16 & 15 & 14 & 13 & 12 & 11\end{array}$

$\begin{array}{llllllllll}10 & 9 & 8 & 7 & 6 & 5 & 4 & 3 & 2 & 1\end{array}$

The paper used in this publication meets the minimum requirements of ANSI/NISO Z39.48-1992 (R 1997) (Permanence of Paper).

Cover illustration: The Iguaçu Falls in the Paraná river basin. Falls and rivers are important barriers to and corridors for dispersal, respectively, in freshwater fishes. The Iguaçu Falls are located at the western margin of the Uruguay / SW Africa megadome, a geological uplift and basalt flow associated with the Lower Cretaceous opening of the South Atlantic and early rifting of South America from Africa. Photo by Marcelo de Carvalho and Robert Schelly. 
But alas! so limited is the scope of science that all one can carry away

of all this beauty is only a memory, and some dried flattened, dead things in blotting paper.

—GORDON MACCREAGH, White Waters and Black

Dedicated to John Lundberg and Richard Vari, for their unflagging devotion to Neotropical ichthyology, and for the many insights they have provided. 
